Research

\title{
Local content implementation and development in Ghana's upstream oil and gas sector for sustainable development: contemporary issues on policy management
}

\author{
Shafic Suleman ${ }^{1} \cdot$ Joshua Jebuntie Zaato ${ }^{2}$ \\ Received: 26 January 2021 / Accepted: 22 March 2021 \\ (C) The Author(s) 2021 OPEN
}

\begin{abstract}
The need to develop and boost the potentials of Ghana's upstream oil and gas activities has been advocated by policymakers, academics, and financial institutions since the discovery of oil and gas in commercial quantities. It has been argued that if well implemented, upstream activities have a trickledown effect on the local content policy linkages that apart from taxes, can lead to improved financial and social benefits. In this study, how Ghana can use local content policy in upstream oil and gas operations to maximum economic and social benefits for the good of the Ghana government, citizens, and the Multinational Oil Companies, is the main question to be answered? To address this question, comprehensive analysis of local content laws and policies and stakeholder consultations are conducted. The paper argues that an effective local content policy towards achieving sustainability in the upstream oil and gas industry demands balancing the needs of policymakers, local communities, Multinational Oil Companies, and regulators to succeed. The study recommends a local content implementation master plan; active participation of key stakeholders (government, citizens and Multinational Oil Companies); and integration of forward and backward linkages in the implementation of Ghana's upstream local content laws and policies.
\end{abstract}

Keywords Local content implementation · Sustainable development · Upstream oil and gas industry · Multinational Oil and Gas Companies · Policy management · Contemporary issues

\section{Introduction}

Resource-rich developing countries are seeking ways to deepen the economic linkages between their extractive sectors and economic development. Countries are increasingly introducing or reinforcing local content policies to stimulate and create value in their domestic economies [1]. Local content policies (hereafter, LCPs) are recognised as important policy interventions for this purpose [2]. According to studies [2-4] LCPs have the potential to do the same for developing countries, especially in Africa where natural resources extraction activities and development are commonly mismatched.

LCPs are heralded because of their ability to bind Multinational Oil Companies (MOCs) to a commitment to developing the host country's economy, instead of simply pursuing profit maximization [3]. Since MOCs operating in developing countries are mostly foreign-owned and largely profit-driven, it has been argued that LCPs offer better opportunities for leveraging petroleum resources to promote active industrialization programmes and stimulate sustainable economic growth for the host country [5]. Linking local content to upstream oil and gas activities could generate social value for the MOCs - an important building block for meeting their sustainable business operations requirements such as the

Shafic Suleman, shafic.suleman@ucc.edu.gh | 'Institute for Oil and Gas Studies, University of Cape Coast (UCC), Cape Coast, Ghana. ${ }^{2}$ Zayed University, Dubai, United Arab Emirates. 
Equator Principles [6]. Many oil-producing developing countries are implementing LCPs intending to maximise the potential of their upstream oil and gas sectors. Developing and implementing such policies remains a huge challenge to some developing countries.

Upstream oil and gas activities in Ghana started in 2007, following their discovery in commercial quantities, and production in 2010 [7]. The Ghanaian government, with an initial aim of maximising royalties and taxes, adopted a'revenuefocused approach' to oil resource management. This was seen as short-sighted because it ignored the potential long-term value addition to the economy [2, 3]. The benefits include localization and scaling up employment, and linkages of local content and corporate social responsibility, in the oil and gas industry [8] for mutual sustainability of stakeholders.

While it is clear that the government of Ghana lacked a comprehensive framework, it is important to note that it has developed and adapted LCPs. These facts raise the main question driving this paper. What policy and regulatory measures are required for an effective LCP in the upstream oil and gas sector in Ghana? This question is timely because while Ghana has argued for the need to liberalise its economy and move away from tax revenues, little has been done in the upstream oil and gas sector despite the continuous dependence on oil tax revenues.

Adapting the local content implementation and development conceptual framework of [9], the study analysed upstream oil and gas industry LCPs and the trickledown effects on the LC framework in Ghana. We seek to explore the role of upstream oil and gas LCPs and management issues presented to the various stakeholders. The paper's point of departure is the observation that the LCP sector in Ghana, as it currently stands, needs improvement [10], as [5] noted, despite Ghana's passage of the local content law, the development of linkages to the economy to capture the direct and indirect impact in the local economy remains a challenge. By answering the critical research question asked, this study makes the following contributions:

- Support an LCP framework for upstream oil and gas activities in Ghana by drawing from both theoretical and empirical evidence.

- Provides theoretical analysis using the LCP framework from Kazzazi and Nouri and a review of perspective in the upstream oil and gas sector through current host government and MOCs commitments towards an improved roadmap.

- Demonstrates that policy-makers and practitioners might intend to create a robust LCP sector, but doing so remains a mirage due to financial and regulatory lapses.

The rest of the paper is structured as follows: Section two focuses on literature review and begins with a definition of local content, LC regulation and upstream oil and gas operations in Ghana; the second section reviews the literature on LC in Ghana and the local content development framework. Section three is the methodology of the study, building on an explanatory sequential mixed-method and the LCP conceptual framework and narrative analysis to support the need for an improved LCP design. Section four provides the discussions and analysis of the study: where LC implementation challenges and gaps in LCP are identified and analysed. And the final section, five, presents the recommendations and conclusion.

\section{Literature review}

Local content policies are part of the broader categories of the "Productive Development Policies (PDP) or Industrial Policies (IP) which include government interventions or policies that seek to increase the share of employment, services, manufacturing and financial value to the local industry value chain [5]. They also comprise initiatives that target the strengthening of the productive sectors of the national economy in manufacturing or agriculture and are measured by the achieved growth or competitiveness of the targeted sector [5]. Ghana's LI 2204 describe local content as "the quantum or percentage of locally produced materials, personnel, financing, goods and services rendered in the petroleum industry value chain and which can be measured in monetary terms".

\footnotetext{
${ }^{1}$ Legislative instrument.
} 
In Ghana, the LC law on Multinational Oil Companies (MOCs) demands that they employ citizens; provide them with training to improve their expertise; prepare and implement plans for technological transfer to the Ghana National Petroleum Corporation ${ }^{2}$ (GNPC); use local raw materials in their operations. This jurisdictional definition is important because the political economy of upstream petroleum production in developing countries has always been dominated by the financial and technological strength of MOCs [3, 11]. Ghana's upstream oil and gas operations are not different, since they are dominated by $\mathrm{MOCs}^{3}$ and major upstream services companies (see footnote 2). The Petroleum Commission ${ }^{4}$ and GNPC serve as agents to the Government of Ghana (GoG) respectively as the upstream regulator and the National Oil Company (NOC), and which together lead the upstream local content implementation agenda. LCPs in Ghana's upstream oil and gas laws include the law establishing the Ghana National Petroleum Corporation, PNDC 5 law 64, and the Petroleum Exploration and Production Acts 919 and 84. PNDC law 64 establishes the GNPC to be mandated to undertake the exploration, development, production, and disposal of petroleum. Additionally, the law states that a contractor or sub-contractor (foreign or local) shall ensure that opportunities are given, as much as possible, for Ghanaians with the requisite expertise in the various levels of operations to be employed. Also, the provisions require contractors or sub-contractors to use goods and services produced in Ghana over foreign goods and services for their operations. Moreover, the contractor or sub-contractor shall, and in consultation with the GNPC, prepare and implement plans and programmes for training Ghanaians in all job classifications and all aspects of petroleum operations. The law further makes it mandatory for a contractor or sub-contractor, to prepare and implement plans for the transfer to GNPC of advanced technological know-how and skills relating to petroleum operations. If this law is properly applied, it will be the basis for upstream LCPs to maximise tangible trickle-down benefits. This study focuses on Ghana's LCPs and implementation at the upstream oil and gas sector and the contemporary challenges for sustainability and policy management instead of a broader comparative study of local content policy implementation as indicated in $[5,13]$. This study presents analysis using the local content development framework [9] for appropriate implementation of Ghana's upstream LCPs and laws. The next section discusses the contemporary issues in Ghana's LCPs.

\subsection{Contemporary discussions on Ghana's local content policy}

Refs. $[8,14]$ noted that the concept of local content in Ghana predates the Minerals and Mining Law, 2006 (Act, 703) and the Minerals and Mining (General) Regulations, 2012 (LI, 2173), which both introduced a local content framework to Ghana's longstanding mining sector. Noteworthy, these laws influenced the Ministry of Energy to stipulate "Iocal content and local participation" in petroleum activities in 2010. Ghana's petroleum local content Regulations 2013 was then passed to promote local content in the oil and gas sector. The framing of Ghana's LCPs is guided by a drive towards employment creation, technology transfer, local ownership, and maximization of local procurement [15]. Ghana's LC law aims to generate positive synergies between the oil industry and the other sectors of the economy [16]. The objectives of Ghana's LC laws, as outlined in LI 2204, are as follows:

- Maximisation of value and job creation through the use of local expertise, goods and services, businesses, and financing in the petroleum value chain, and their retention;

- Develop local capacities in the petroleum value chain through education, skills transfer, and expertise development, transfer of technology and know-how, and active research;

- Achieve the minimum local employment level and in-country spending for the provision of goods and services in the petroleum value chain;

- Achieve and maintain a degree of control for Ghanaians over development for local stakeholders; and

- Transparent monitoring and reporting systems to ensure delivery of LCP objectives.

Ref. [8] identified the Government of Ghana (GoG), Multinational Oil Companies (MOCs), and the citizenry as the major stakeholders in Ghana's oil and gas local content structure. Employment is the main expectation of the citizenry. But

\footnotetext{
2 Service Companies such as Schlumberger, Baker Hughes and Halliburton.

${ }^{3}$ MOCs such as Tullow, Kosmos, Anadarko, ENI, Aker, and ExxonMobil.

${ }^{4}$ It is an approach combining qualitative and quantitative data collection and analysis in a sequence of phases. In the first phase, researchers collect qualitative data and then analyse the data, the results of which direct the next, quantitative phase, which could be a questionnaire, survey or some other form of quantitative data collection [12].

5 Provisional National Defence Council.
} 
even this idea is bedevilled with numerous barriers to localizing jobs, such as limited experience, qualifications, and skills levels within the local labour market, a lack of understanding among local people of the parent organization culture, and the preference for employing expatriates by MOCs [8].

Nevertheless, [17] suggest that Ghanaians dominate onshore administrative positions and the lowest echelons (rating)/low skill positions offshore. Notwithstanding, there is a significant salary disparity between Ghanaians and expatriates due to poor regulation by the Petroleum Commission, corruption, and undercutting by local recruitment agencies. Meanwhile, the government has not yet offered skill enhancement programmes for Ghanaians in the industry [14]. The lax enforcement of regulations by the Petroleum Commission on a national scale creates an environment for expatriates to commit malpractices such as slowing skill transfer [17].

Furthermore, [18] indicate that the Petroleum Commission (PC) was found negotiating with MOCs to award contracts in smaller units, a scale on which Small-to Medium-scale Enterprise (SMEs) could meet the financial requirements. The MOCs noted, however, that awarding contracts in smaller units could increase their operational costs. Additionally, the high-interest rates charged on loans from banks in Ghana makes it difficult for SMEs to procure loans to finance their businesses. Most of the Ghanaian banks lacked an understanding of the operations of oil and gas and were not ready to finance SME activities in the petroleum sector. Institutions such as the Petroleum Commission and the Ghana Standards Authority (GSA) must enforce local standardisation measures that are easily obtainable by local SMEs and acceptable to MOCs.

According to [17] the primary factors driving local content implementation in Ghana are neither institutions nor broad politics, but rather inter-elite power relationships within the ruling coalitions, underpinned by interests and ideas. Ref. [19] examined the GoG's local content flagship project, Enterprise Development Centre (EDC), ${ }^{6}$ a 5 -year project established to enhance the capacity of Ghanaian SMEs in the oil and gas industry. Driven by the desire to appeal to voters, the ruling government implemented the EDC project without broad consultation. Consultations with these small to medium scale businesses concluded that most of them lack the financial capital, technical expertise, and competitiveness to engage effectively. Ref. [18] identified limitations in the implementation of the backward and forward linkages in the industrialization processes associated with the local content law.

The literature on Ghana's oil and gas local content laws has so far focused extensively on employment, local content implementation politics, and the role of Small to Medium Scale Enterprises in the implementation of local content laws. The broader context, exemplified by the case of $[5,13]$ and its significance for broad-based LCP sustainable development and implementation framework has been minimally researched. We believe that a comprehensive analysis of the constraints and opportunities of the LCPs in the upstream oil and gas industry is required to formulate a coordinated strategy. Such an analysis will be sustainable to all parties involved (GoG, MOCs and citizens) [5] and policymakers, practitioners, and community leaders who seek alternatives to the status quo. The next section proposes such a framework.

\subsection{A framework for analysing local content development in Ghana}

Ref. [9] developed a local content conceptual model aimed at incorporating all important factors to provide a comprehensive and coordinated strategy. Some factors such as local policies, local infrastructure, local environment, and local capacities categorized as variables impact on local content development and implementation (see Fig. 1). These factors were developed through empirical and theoretical studies in the petroleum industry and tested for their appropriateness and validity in creating value for the host country.

There is a strong relationship between a sustainable local content development and implementation and the aforementioned variables. Ref. [9] note that, local content development and its sustainability is found to have an impact on local infrastructure, local policies, local capability, and the local environment. Characteristic of enablers of local content development is their potential to influence the promotion of local content processes.. Countries benefit from local content development in three main forms: economic growth, industrial growth, and spillover effects. Some of the dominant factors that have a direct impact on the oil and gas sector in Ghana include the following:

\footnotetext{
${ }^{6}$ The Enterprise Development Center (EDC) was established after the passing of the LI2204 on local content between the Ghana government with the Jubilee Partners, a consortium of international oil companies, in a town called Takoradi, with the aim of enhancing the capacity of Ghanaian businesses in the oil and gas industry [18]
} 


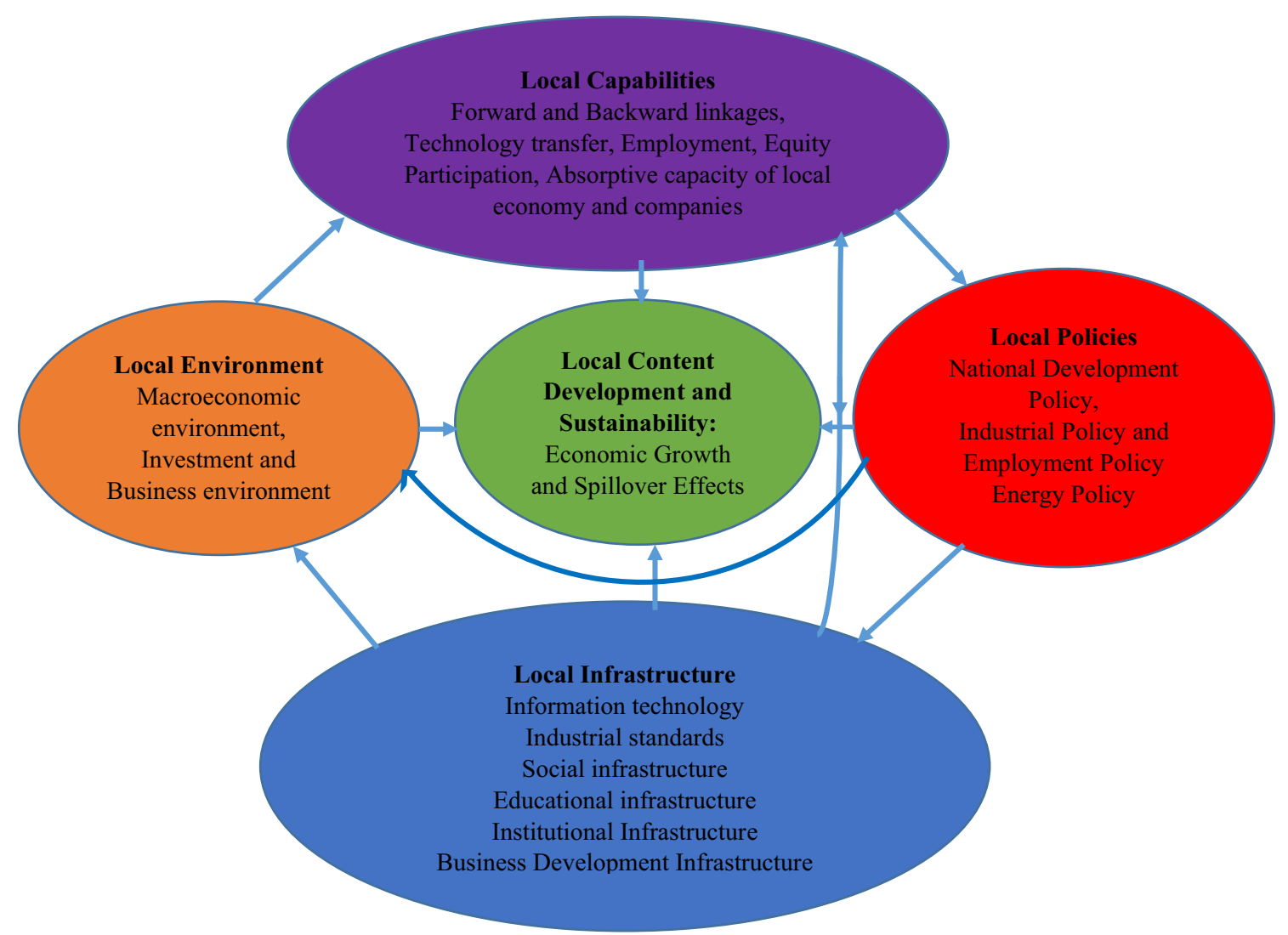

Fig. 1 Conceptual model for local content development in Ghana (Adapted from [9])

\subsubsection{Local policies}

Local policies cut across all sectors in every economy, including the oil and gas sector in the oil-producing countries. Such policies are designed to stimulate local development in manufacturing and services; they generally forecast the macroeconomic environment, increase the reliability of institutions, offer incentives to enhance sound business practices, generate an enabling infrastructure for business development, and enhance social structures. The broad policies for local content development in Ghana are the National Development Plan, Industrial Policy, Local Content Policy and Laws, Employment Policy and the Energy Policy. They require the domestication of natural resources for development.

\subsubsection{Local infrastructure}

Public utilities, such as roads, railways and air transport, telecommunications, and electricity and water supply, as business environment infrastructure, can create an environment that enables business development and productivity. Also, the internet technology infrastructure is an important variable for local content development that enables information dissemination in the oil industry. Social infrastructure, on the other hand, is associated with social cohesion between different stakeholders, which reduces the chances of social disorder; a stable environment attracts foreign investment and technology transfer [20].

\subsubsection{Local capabilities}

Local capabilities are a set of factors including education, skills, and development; transfer of technology and know-how; active research; and development portfolios within the manufacturing and services of local companies. Developing local content in the petroleum sector must be based on existing capabilities within manufacturing, fabrication, and services that includes backward and forward linkages to the local economy. Local policies have to appreciate and encourage foreign firms to collaborate with local companies. Industrial development is a learning process where capacity and 
capabilities expand through problem-solving tasks in collaboration with international, leading competences. The absorption capacity of the local company is crucial for technology transfer.

\subsubsection{Local content development and sustainability}

The extent of local content development in most countries depends entirely on the quality of relationships between the political, infrastructure, environmental, and local capability factor. LCPs encourage economic diversification, backward and forward linkages are necessary because they are a trade-off between short-term efficiency and long-term economic development. When applied, LCPs could coordinate through value chain analysis that can facilitate the competitive participation of domestic firms in the local petroleum industry [20] and sustainable benefits for the stakeholders (government, MOCs and citizens). Improper application of LCPs may be harmful to the economy of the host country, operations of the MOC and living standards for the citizenry. The above review demonstrates the requirements of an effective LCP for Ghana as it strives to enact its upstream LCPs. The next section considers the study methodology.

\section{Research methodology}

In this study, narrative and content analysis of local content policies in the upstream oil and gas sector in Ghana for the period 2010 to 2020 was conducted using Kazzazi and Nouri's conceptual framework (discussed above). This was augmented with primary data from semi-structured interviews. Ref. [21] defined narratives as the kind of organizational scheme that is expressed in story form. Narratives provide grounded arguments to compare and contrast performance and enable the construction of narrative strategies [22]. This study uses narrative analysis because there is a long record of narratives in the implementation of local content in Ghana's oil and gas sector.

An explanatory sequential mixed-method (see footnote 4) research design [12], guided the study as we sought to profit from the strengths of the approach in offering valid conclusions on the subject under investigation. The selection of participants and organizations for the study and interviews was done by purposive sampling, a widely used nonprobability sampling [23]. This approach granted us more control, freedom and influence over the choice of organizations and personnel that better suits the needs of the research. It also enables researchers to select participants with the requisite knowledge and experience to respond to interview questions and provide a better insight into the issues under discussion [24]. The inclusion criteria were organizations/institutions and communities that were directly or indirectly involved in the upstream oil and gas sector in Ghana. A total of 12 major stakeholders were identified, approached with an ethical clearance form to seek their consent and acceptance and willingness to participate.

All the 12 stakeholders agreed to participate. They were further categorized into five groups: Government Agencies (the Ministry of Petroleum, the Petroleum Commission, and the Ghana National Petroleum Corporation); educational institutions (GNPC Research Chairs in the three leading public universities in the country); upstream production companies (Tullow-Ghana, and ENI-Ghana); upstream service companies (MODEC, Baker Hughes, Schlumberger and Haliburton); and local communities (Secondi, Takoradi, Cape Coast). We sent these organizations/community leaders emails inviting them to participate. About $98 \%$ responded, and we scheduled times and venues convenient for them. The interviews were conducted in November and December 2019 at their premises. They were interviewed, based on their activities in the upstream oil and gas industry and the enforcement of local content laws in Ghana. Each interview lasted for about $45 \mathrm{~min}$.

Each interview guide was made up of open-ended questions. Such questions gave the respondents enough leeway to answer the questions fully while providing explanations and clarity [25]. It is an approach that also enables follow up questions for further clarification. It suited the research needs best because the open-ended nature of questions granted greater flexibility in the actual interviewing process.

The interviews were recorded with the consent of the respondents. Also, notes were taken using the long-hand method. The notes helped us to probe further if answers were not clear or if someone contradicted an earlier interviewee. The responses were later transcribed and compared during debriefing sessions to determine bias and exaggerations, thereby ensuring the validity and reliability of the data provided [24]. This was done to ensure the validity and objectivity of the data collected. 
The second approach was a documentary review, ${ }^{7}$ which, according to [26], secondary data in a quantitative format on local content development in Ghana for the period 2010-2020 was collected from two sources (government agencies and review of local content literature). Upstream oil and gas employment and in-country spent data from the interviews and data from the Petroleum Commission were further collected and inputted into Microsoft Excel and tables and bar graphs generated for the study. These include the annual reports, newsletters, press releases, and company presentations published on government, civil society, and International Oil Companies websites. Content and narrative analysis is used for coding and identifying themes or patterns in the secondary data [27].

The use of narrative and content analysis and semi-structured interviews generated a good level of objectivity in both the collection and analysis of data. It ensured that we could cross-check and verify the accuracy and validity of the data. Using this data, the next section examines the main bottlenecks of the implementation of local content laws in the upstream oil and gas sector in Ghana.

\section{Discussions}

This section uses the above discussions to answer the main research question. How can Ghana effectively develop and implement LCPs in the upstream oil and gas sector?

\subsection{Local environment}

Kazzazi and Nouri's framework on the local environment is analysed from the Ghanaian perspectives. What local environment is required to implement Ghana's LC policy in the upstream oil and gas segment? Ghana's economic strategy since 1992 has focused on macroeconomic stabilization and structural reforms in a democratic environment. In 1990, the government set up the National Development Planning Commission (NDPC), charged with formulating and implementing an enhanced economic strategy to consolidate the gains achieved by the Economic Reform Programme (ERP) and to lay the foundation for accelerated economic growth and poverty reduction in the twenty-first century [28]. The ERP included adopting neo-liberal policies to reduce the high macroeconomic imbalances and liberalize the external sector [5]. These reforms have catapulted the country to become one of the fastest-growing economics in the world, as well as in Sub-Saharan Africa and attain low-middle income country status. Ghana's economy in the first quarter of post-oil production in 2010 grew at 14.5\%, 7.9\% and 7.4\% GDP in 2011, 2012 and 2013 respectively [5, 28]. The services sector continues to occupy the largest share of the Ghanaian economy with $46.3 \%$ in 2018 . This is followed by the industrial sector with $34.0 \%$ and the Agriculture sector of $19.7 \%$ in 2018 [29].

Ghana has an enabling business environment. The country is one of the most attractive locations in Africa for doing business. It is a stable, multiparty, parliamentary democracy and committed to market liberalization with a sound macroeconomic environment and immediate access for all markets of the Economic Community of West African States (ECOWAS). Ghana host the secretariat of the African Continental Free Trade Area (AfCFTA), a flagship project of the African Union (AU) to bring together 55 African countries with a combined population of about a 1.2 billion people and worth estimated in 2017 of more than US\$2.5 trillion. The country stands to benefit from AfCFTA and its anticipated positive impact on growth through several channels, including a large market outlet, high investment, deepened Intra Africa trade, welfare benefits from lower import prices, production efficiency, increased outputs, higher value-added jobs and exports, technological specialisation and infrastructure investment [29].

Other objectives are the on-going privatization of major economic sectors, infrastructure development, expanding stock markets, a competitive labour force, fast-developing financial infrastructure, and a high degree of personal safety [30]. Ghana performs creditably well in the governance of its oil and gas resources. It scored 67 out of 100 points from the global Resources Governance Index, making it the best performing extractive country in Sub-Saharan Africa [31]. Ghana has demonstrated that it has an enabling environment, with social and local infrastructures adequate for the development and implementation of LC in the upstream oil and gas sector $[9,20]$.

\footnotetext{
7 It's a systematic procedure for reviewing or evaluating documents-both printed and electronic (computer-based and Internet-transmitted) material [26].
} 


\subsection{Local policies}

The legislative and regulatory framework for upstream oil and gas development is governed by six basic laws: The Petroleum (Exploration and Production) Act, 1984 (PNDC Law 84); Petroleum Exploration and Production Act, 919, 2016; the Ghana National Petroleum Corporation Act 1983 (PNDC Law 64); the Petroleum Income Tax Act, 1987 (PNDC Law 188); The Petroleum Commission Act, 2011, Act 82; and the Petroleum Revenue Management Act, 2011 (Act 815 ).

The Model Petroleum Agreement and the Exploration and Production Act 919, 2016 are the basis upon which all petroleum agreements are negotiated in Ghana [5]. The GNPC Act, 1983 (PNDCL 64) and the Petroleum Commission (PC) Act 2011 (Act, 821) established, respectively, a national oil company, GNPC, and an upstream petroleum resources regulator Petroleum Commission. The GNPC is, among other things, responsible for ensuring that Ghana obtains the maximum possible benefits from the development of its petroleum resources; secures the transfer to Ghana of appropriate technology in petroleum operations; facilitates the training of Ghanaians, and the development of national capabilities in all aspects of petroleum operations [32].

The Petroleum Commission is mandated to manage and regulate the petroleum resources and coordinate implemented policies in the upstream petroleum sector [33]. The commission is responsible for, among other things: promote local content and local participation in petroleum activities as prescribed in the legislative instrument (LI 2204) and other applicable laws and regulations [33].

The GNPC, when well-governed, its laws adequately implemented, would ensure effective upstream LC development and implementation in Ghana [34]. The GNPC's activities over the years have resulted in accelerated commercial upstream petroleum discoveries and production in Offshore Tano, West Cape Three Points, Saltpond and the Keta basins. Through the activities of the GNPC, Ghana's upstream petroleum operations have rapidly transformed on every front in investments, the scale of operations and new institutions [32]; the GNPC should, however, aim to achieve higher global standards and be the engine of national development [34] and the "poster child" for Ghana's upstream oil and gas LCPs.

With regards to the development and implementation of LC, the GNPC admits its inability to ensure the training and development of national capacities in all aspects of petroleum operations. Beside joint venture operations with International Oil Companies (IOCs), the GNPC has not developed solely, any upstream infrastructure for oil and gas production in Ghana. Furthermore, the corporation has been unable to meet the country's national petroleum requirements, making it a net importer of petroleum products despite trading crude oil to the global market depriving of the internal domestic refinery market. The problem is a poor LC forward linkage of integrating upstream crude oil production to an existing (Tema Oil Refinery) refinery capacity. It also prevents Ghana from obtaining adequate benefits from its petroleum resources, except that from petroleum revenues and limited employment opportunities in the upstream sector.

The GNPC encounter challenges, ensuring the transfer of technology from MOCs in operationalizing their mandate. The recommendations to GNPC effective performance and implementation of LC include the GNPC defining a commercial mandate and financing commercial activities, and attracting adequate debt and equity financing; limiting political interference in technical decisions, and investing in staff capacity and integrity; and ensuring transparency and oversight of the activities of their LCPs [34]. The Petroleum Commission is mandated to effectively implement the LC legislation (LI. 2204) as the regulator.

\subsection{Local capabilities and infrastructure}

The local capabilities and infrastructure of [9] framework are mutually inclusive and combined into equity participation; financial (local content fund and in-country spend), employment, forward and backward linkages; technology transfer and; research and development [9].

\subsubsection{Equity participation in upstream operations and service provisions}

In the Local content $\mathrm{LI}$, an Indigenous Ghanaian Company (IGC) shall be given first preference in the grant of a petroleum agreement concerning petroleum activities. Also, there shall be $5 \%$ equity participation of an IGC other 
Table 1 In-country spending of petroleum operations in

Ghana. Source: [33]

\begin{tabular}{lrrr}
\hline Contracts awarded from 2012 to 2019 & & & \\
\hline Ownership structure & Contract value (USD) & $\begin{array}{l}\text { Round off (Billion } \\
\text { USD) }\end{array}$ & $\%$ \\
\hline Foreign & $8,977,036,478.03$ & 9.00 & 55 \\
Indigenous Ghanaian Company (IGC) & $1,193,107,537.90$ & 1.20 & 7 \\
Joint Venture (JV) Company & $6,167,759,587.06$ & 6.20 & 38 \\
Total & $16,337,903,602.99$ & 16.40 & 100 \\
\hline
\end{tabular}

than the GNPC to be qualified to enter into a petroleum agreement. Additionally, a foreign company that intends to provide goods or services in the petroleum sector shall incorporate a joint venture company with an IGC and afford that IGC equity participation of at least $10 \%$.

Despite the aforementioned good intentions of the law, there are still many pressing constraints. The main challenge on the IGC $5 \%$ equity participation in upstream operation is the difficulty in accessing financing to pay for their equity. Also, very few IGCs can absorb the risk of cash calls for exploration activities and the potential and real risk of no discovery can subsequently negatively impact the survival of the IGC. Additionally, the $5 \%$ equity participation is inadequate to participate significantly in management and ownership control. In this regard, the IGC is used only to acquire petroleum agreements and licences. It is not allowed to participate adequately in the decision-making and operations of a joint venture. This obstruction undermines the purpose of skills acquisition and technology transfer to IGCs. That is why we agree with the suggestion of the [30] that Technical Partnership Agreements should be signed, with IGC, instead of just a joint venture that allows Ghanaians to be part owners of the contracts with the foreign companies. Doing so will include them among the drivers of execution, giving Ghanaians some management and operational control. When the Petroleum Commission properly monitor this, the transfer of skills and technologies to the IGC could be successful.

\subsubsection{Establishing a robust financial link}

From 2011 to 2018, Ghana received US\$4.97 billion and distributed US\$5.013 billion as cumulative revenues from upstream oil and gas operations in the form of royalties, participating interest, taxes, interest, surface rentals, and gas revenues [35]. The Petroleum Revenue Management Act (815), amended as Act 893, stipulates the distribution of petroleum revenues, and the Bank of Ghana receives these funds into a Petroleum Holding Fund. Not more than $55 \%$ of this revenue is allocated to the Ghana National Petroleum Corporation (GNPC). The remaining $45 \%$ is distributed as follows. Not more than $70 \%$ is given to the Annual Budget Funding Amount (ABFA). Out of the ABFA fund, not more than 30\% is allocated to the Ghana Infrastructure Fund, the Public Interest and Accountability Committee, and selected priority areas of investment for the country. The remaining $30 \%$ of the $45 \%$ is disbursed into the Ghana Petroleum Funds [27, 35].

The GNPC uses $55 \%$ of its share of petroleum revenues to finance its upstream operations and increase its equity participation. The Ghana Government uses the ABFA to finance government expenditure on goods and services and the remaining amounts for public investment expenditure. This way, the economy of Ghana benefit from these oil revenues for national development [35]. Funds from petroleum revenues should be used to provide some of the critical infrastructure (roads, rails, and ICT), as [9] noted, which are required to sustainably implement LCP. This would address some of the critical infrastructure issues in the upstream oil and gas sector. Also, investment should be channelled towards providing new and improving existing physical and social infrastructure at the upstream in collaboration with the GNPC. Some funds can be made available to provide financial support to the IGC to compete with their foreign counterparts in the services sector. The petroleum revenues can provide seed capital for the local content fund and serve as leverage to develop critical infrastructure to scale-up indigenous participation.

\subsubsection{The lack of local content fund}

We found that financial constraints serve as a roadblock to Indigenous Ghanaian Companies (IGC) participation in the upstream oil and gas sector. Ref. [25] identified two aspects of the problem viz ineffective capital mobilization and higher interest rates. The long-term financing needs of the oil and gas industry remains a challenge due to the lack of specialized investment banks. Syndicated loans could solve the problem, but local banks lack adequate capital and cannot support the high-risk exposure in the upstream oil and gas sector. To solve the local content funding 
Fig. 2 Upstream localization of employment in Ghana (Source: [33])

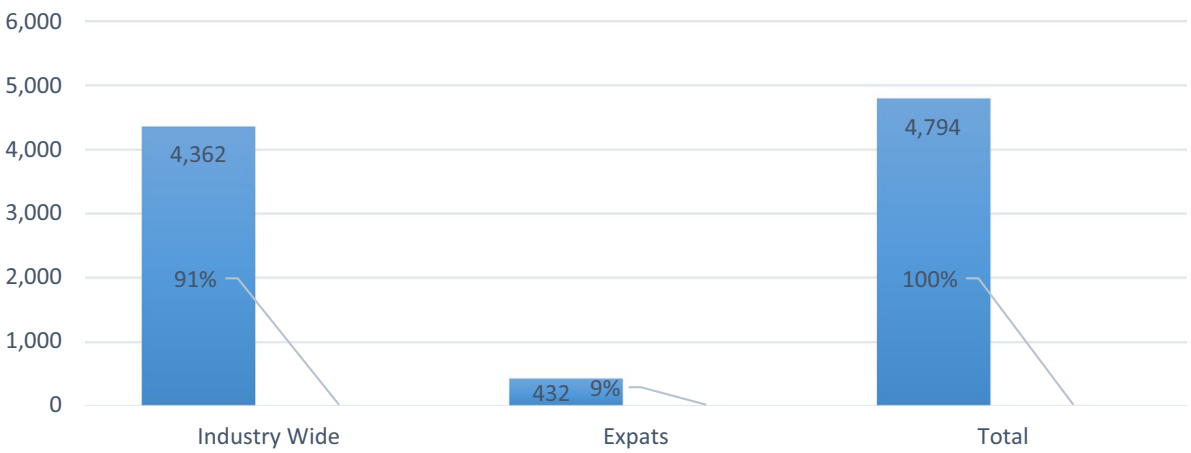

problem, the Oil and Gas Business Development and Local Content Fund (OGBDLCF), supported by the MOCs, was established to support education, training, and research and development for the government to address the human resource gap. The Petroleum Commission is currently developing guidelines to operationalize the local content fund (LCF). This fund is supposed to provide financial assistance to the IGCs to help them compete in the sector. The LCF is supposed to be funded by $1 \%$ of every contract signed in the sector. However, there is very little cooperation from MOCs in contributing to the LCF. While the idea might be welcoming for local companies, it's not in the long-term interest of the MOCs. Stricter enforcement and supervision or a consultative approach is required to compel/convince the MOCs to honour this contractual requirement of funding the LCF.

\subsubsection{In-country spending by MOCs}

LCPs can be used as a tool to develop local supply chains [1] when goods and services are procured locally and projects contracts executed by IGCs, but this is minimally done in developing countries [3]. Evidence from the Petroleum Commission indicates that from 2012 to 2019, in-country spending along the oil and gas value chain was US\$16.4 billion. Foreign companies received 55\% (US\$9 billion), IGCs 7\% (US\$1.2 billion), and Joint Venture (JV) companies $38 \%$ (US\$6.2 billion), as shown in Table 1.

IGCs receive a marginal share of 7\%, representing US\$1.2 billion out of a total of US\$16.3 billion of the in-country expenditure in the upstream oil and gas sector within 7 years of operation (2012 to 2019). Upstream contracts going to foreign companies (55\%) are still far greater than the combined contracts going to both IGCs and JVs (45\%). The in-country spending, procurement of goods and services, and joint venture activities are a significant source of both direct and indirect benefits of the oil and gas industry to the Ghanaian economy. The in-country spending can be re-strategized to ensure that a majority goes to IGCs through joint ventures, as stipulated by the local content law (LI.2204), which requires oil and gas service companies to form joint ventures with IGCs with 10\% equity participation. Also, IGC $10 \%$ of equity participation needs to be monitored by the Petroleum Commission (PC) to ensure that the IGCs benefit in full from this law.

There is, however, resistance from the MOCs to the implementation of the $10 \%$ joint venture equity participation with IGCs. For instance, a respondent (Senior Manager-Expatriate) with a Multinational Oil Companies narrated, "Their companies are of international repute, and they cannot give 10\% ownership to an IGC. Even a local subsidiary of our companies does not merit any JV with an IGC".

While this concern is legitimate, the PC can consider service JVs on a contract award and execution basis instead of company ownership. Furthermore, while contract awards going to foreign companies can be discouraged, joint venture operations should be encouraged through joint operating agreements for IGCs to learn from their foreign counterparts in the areas of joint management, control, and operation of projects/contracts. At the same time, an IGC that is credible enough to be on its own should be encouraged and promoted while preventing fronting [18] tendencies, which is, a criminal offence in Ghana [36].

It is noteworthy that the in-country spending total of US\$16.3 billion over the past 7 years is twice the amount of direct oil revenues (US\$4.97 billion) to Ghana's government. It implies that the LCP should target the optimization of in-country spending towards IGCs. In-country spend has an indirect effect, driving benefits from the oil and gas industry as [5] indicated in the Norwegian case, where the services and supply industry currently generating over US\$64 billion annually. 
Fig. 3 Upstream employment roles in Ghana (Source: [33])
- Ghanaians $\quad$ Expatriates

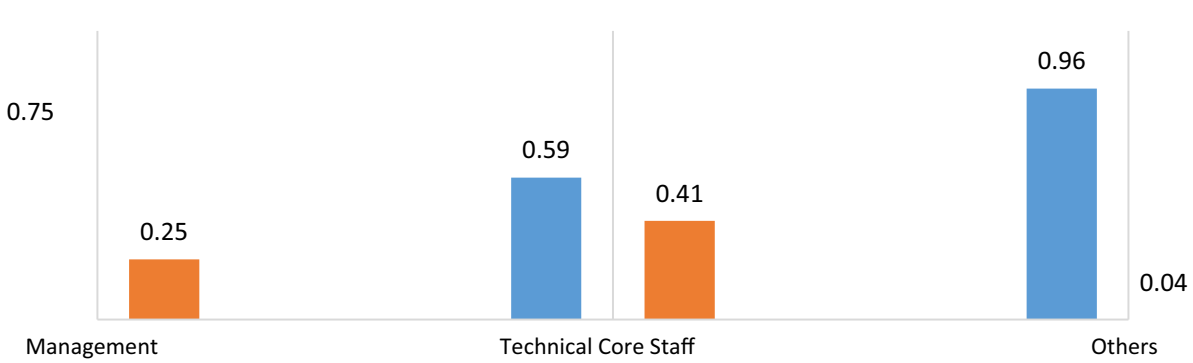

Furthermore, according to [37], between 40 and $80 \%$ of the revenues generated in oil and gas are used to finance procurement of goods and services and the spillover effects, which often exceeds the benefits from tax and royalty payments and therefore merit the focus of the LCP on in-country spend.

\subsubsection{Employment linkage}

The local content law LI 2204 on employment requires that a company operating in Ghana for 10 years must employ $70-80 \%$ managerial, $70-80 \%$ core technical, and $100 \%$ of other Ghanaian staff. Data from the Petroleum Commission indicates that as of 2019, about 4362 (Industry-Wide) Ghanaians were employed in 30 companies operating in the upstream oil and gas industry. This represents $91 \%$ of the total workforce, foreign expatriates $9 \%$ of the employment position (see Fig. 2).

The number of expatriates employed in the upstream oil and gas sector in Ghana is significantly marginal, representing $9 \%$ out of the total 4794 employees working in the upstream sector. However, further analysis of the $9 \%$ is key to ascertaining their roles and responsibilities and potential opportunities for replacement with Ghanaians.

A further breakdown of categories of the upstream employment roles in Ghana shows that Ghanaians represent $75 \%$ of management roles and expatriates $25 \%$ (see Fig. 3). The majority of the $9 \%$ of expatriate workers are in the management segment. Further investigation is also required to ascertain which managerial positions Ghanaians occupy.

There were also constraints on the impact of the managerial roles occupied by Ghanaians. As indicated by a respondent (Senior Manager MOC_-Ghanaian), "Not all managerial roles are strategic or technical and the MOC appoint Ghanaian managers to meet the local content law requirement, but these managers do not have any significant impact on strategic decision making in the MOC".

Even though Ghanaians can be appointed as managers of MOCs, the level of their participation and control remains questionable. Most importantly, which part of the decision value chain are they managing? What are the financial authorization limits for him/her? And, finally, who is he/she responding to? Another respondent (Senior Manager, MOCGhanaian) said: "The MOC has a Ghanaian country director, who operates the MOC Ghana office solely, and reports directly to the overseas head office. The manager was recruited, at the head office overseas. This manager takes all the operational, technical, and strategic decisions in-country, and has a financial authorization limit of US\$400million. He meets weekly with the company's board of directors and with his other colleague managers from other subsidiary country offices".

On the same issue, another respondent (Senior Manager, MOC-Ghanaian) stressed that "the MOC has an ex-pat from Headquarters office as the stationary manager, but a Ghanaian local content manager is acting mostly as the country manager. The less active ex-pat manager, however, is the final authorization point, and reports to the MOC head office outside Ghana".

The difference in the two managerial level roles cases affords a sound understanding of the extent of their control and the ability of two Ghanaian senior-level managers working in two different MOCs to exert any strategic managerial control. The difference between the two managers for the two MOCs is in their control and authority to make in-country financial and strategic decisions. While the manager of the MOC in the second case is constrained by an expatriate, the first reports directly to the headquarters. The Petroleum Commission need to investigate the roles of Ghanaians in managerial positions of MOCs upstream.

In the core, technical roles Ghanaians are $59 \%$, and expatriates are $41 \%$. This low representation of Ghanaians in the technical core staff in upstream operations undermines a core aspect of the local content law which requires $70-80 \%$ as Ghanaians after 10 years of operation. We agree with [38] that, the upstream oil and gas industry is highly capital intensive, and low in labour intensity [38]. The few jobs available from upstream operations are very technical and highly skilled, such as engineering and higher management positions. This shortfall emerges from the lack of Ghanaian workers 
with core technical expertise in upstream oil and gas operations and the challenge of enforcing knowledge and skills transfer from expatriate technical staff to their Ghanaian counterparts in the upstream [8]. Until this is addressed, the idea of knowledge and skills transfer as required in the implementation of the local content law in Ghana will remain a mirage. To address this, Local Training in core technical skills (e.g., drilling, engineering, geosciences, and technical management) needs to be scaled-up and mentoring, experience building and efforts to localise core technical positions should be encouraged [8]. Training and education in technical expertise in the upstream sector are thus paramount [15].

\subsubsection{Technological transfer}

LC LI (2204), The Petroleum (Exploration and Production) Act, 1984 (PNDC Law 84); Petroleum Exploration and Production Act, 919, 2016; and the Ghana National Petroleum Corporation Act 1983 (PNDC Law 64) requires that technology be transferred from MOCs to local companies. The [9] LC framework notes that the absorptive capacity of the GNPC and IGC are crucial in technology transfer. Technology transfer in the upstream oil and gas segment in Ghana is minimal, as [25] agrees. Mentorship is the best way to achieve this objective, but as one respondent (GNPC Professorial Chair) observed, "It is interesting to note that none of the MOCs will willingly transfer technology to the GNPC or IGC. Technology is not transferred willingly, unless it's stolen". This indicates the magnitude of the constraint and means that even in the best of circumstances, it is difficult, if not impossible, to have technology transfer until concerted efforts are made by the PC to ensure effectiveness. PC must develop a technology transfer plan to provide a roadmap for successful implementation.

\subsubsection{Research and development}

With research and development, the LC LI 2204 requires MOCs to ensure that their research and development activities concerning the oil and gas industry are conducted in Ghana. The PC LC enforcement efforts achieved little in petroleum research activities in Ghana. Meanwhile, in 2018 the GNPC established four research chairs in four public universities to accelerate research and training in upstream oil and gas activities. A US\$1 million research endowment fund is available to each of these institutions to establish new training programmes and research into petroleum-related activities for GNPC and Ghana at large. While this is an opportunity to contribute significantly to research and development in the sector and encourage academic talent, the GNPC's initiative should be supported by the PC, and scaled-up to be more inclusive and sustainable while the management and disbursement of the funds need to be improved. MOCs can also replicate or support GNPC's efforts.

\subsubsection{Forward and backward linkages}

The backward linkage refer to the inputs used for the production of the staple [5]. This arises from the procedures that supply inputs to the production of the commodity with interest in local firms providing services and supplying inputs to the oil industry in the country $[14,17]$. The capacity of local companies to supply goods and services to meet demands of upstream oil and gas operations are proven as evidenced by the backward link. IGCs have low to moderate capacity to take up opportunities in the core technical areas where MOCs tend to spend more; these include well-drilling services, Front End Engineering and Design (FEED) services, detailed engineering, and fabrication, among other services. Many local companies tend to focus on the non-technical areas of transportation, supply, and disposal, environmental health and safety, IT, and communications.

This limits the opportunity of local companies to build advanced technological competencies for opportunities in the backward linkage. It also shows why IGCs play a less significant role in in-country spending. The in-country spending and backward linkage are directly related; until when IGCs are adequately prepared to offer goods and services to the MOCs competitively, less will be achieved through the backward linkage. This is why the LC Funds in research and development and technological transfers should be targeted to IGCs to improve their performance to enable their contribution in the upstream oil and gas sector through the backward linkage.

The forward linkage provides direct and indirect benefits to the Ghanaian economy, as seen in the benefits of natural gas utilization for power generation and liquefied petroleum gas for domestic use [39]. Little, however, can be said about crude oil. There could be enormous benefits from it when crude oil is supplied through the Domestic Supply Obligation to be refined locally for local consumption and use in petrochemical industries. 


\subsection{Local content development and sustainability}

LCP and sustainability in Ghana's upstream oil and gas industry: local content laws and policies if well implemented will benefit the key stakeholders: the Ghana government, the citizens and the MOCs. When sustainable local content policies are developed, Ghana's economy will grow and with intended spillover effects. This will create possibilities of linkages with the industrial and service sectors of the economy. The overall economic growth will lead to higher living standards and create employment opportunities at various levels, including upstream, midstream and downstream sectors of the petroleum sector. This could be realized from the trickle-down effects and the backward and forward linkages. Also, MOCs will benefit from sustainable local content development through reduced social and environmental risk (Equator Principle). This will be achieved when their activities translate to positive gains to the country's economic growth, stability and employment for the citizenry.

\section{Conclusion}

The study established that Ghana needs to sustainably manage the direct and indirect potential of the oil and gas resources and windfalls into long-term prosperity using LCP as the tool. The above discussions show that Ghana's oil and gas industry could contribute substantially to economic development if effective and sustainable LC laws and policies are implemented. The LI 2204 can be implemented in the broader and inclusive context of [9] LC framework, with the MOCs, PC, the GNPC, IGCs and citizenry playing active roles. The financial link can serve as leverage through which the Local Content Fund will be established to provide financial support to IGCs, which would have the potential to enhance, first, employment, and then forward and backward linkages to the economy. This study recommends a strong connection with the financial link to provide support in capital and lower interest rates, building capacities in training and research into the oil and gas sector to further boost inflows to the economy at large.

The Government of Ghana gas infrastructure has provided stable and less expensive power to maintain macroeconomic stability. Establishing robust forward and backward linkages from the oil and gas industry in Ghana, like an integrated petrochemical industrial hub, has the potential to transform the Ghanaian economy. The Petroleum Hub Bill 2020, recently passed in Parliament, is in furtherance of this objective, which needs further research.

The Government of Ghana, the GNPC, and the Petroleum Commission should not only serve as passive actors and providers of regulations. They need to act as strategic agents in creating an enabling environment for the effective implementation of LC laws. They also need to take actions to increase the government's stake in petroleum agreements; help develop skills; provide infrastructure; develop customised/local based technologies; provide financial support, and coordinate with IGCs to boost local participation in the upstream oil and gas sector. The PC can further offer a common platform for all the stakeholders (MOCs and citizens included) involved in the upstream oil and gas sector on which to discuss local content implementation strategies in a transparent and accountable manner. As a recommendation, Ghana should consider developing an LC implementation Master Plan, like the Ghana Gas Master Plan and the Ghana Renewable Energy Master Plan [40], for an integrated roadmap for sustainable local content development.

\section{Data availability statement}

The data used for this study were guided during a Local Content Conference held on the 20-22 November, 2019 organized by Petroleum Commission of Ghana: the conference details are available here: Presentations-2019 LCCE (ghanalcce.com) Program Line Up-2019 LCCE (ghanalcce.com) 2019-LCCE-Final.pdf (ghanalcce.com) 2018-LCCE-Brochure.pdf (ghanalcce. com). A letter was written to Petroleum Commission requesting for local content data and information and this was also made available but also subject to third party restrictions.

Semi-structured guided in-depth interviews were also conducted with Multinational Oil Companies and GNPC Professorial Chairs in the three public universities in Ghana and audio recorded. During the seeking of their consent and ethical clearance, they agreed that parts of their interviews can be used in the study but should not be shared where the authors do not have control of the extent of use. This was agreed before they agreed to participate and signed the consent forms. The interviews data conducted are subject to third party restrictions and participants do not want their data shared. 
Authors' contributions (1) Both authors collected the data. (2) Both authors wrote the first draft through the sharing of ideas from the main research data. (3) This publication is a part of a series of other publications and both authors are part of the process of data collection, analysis and presentation. (4) Both authors added references and reviewed the manuscript. (5) Both authors responded to reviewers comments and preparing manuscript for publication. Both authors read and approved the final manuscript.

\section{Declarations}

Competing interests The authors declare no competing interests.

Open Access This article is licensed under a Creative Commons Attribution 4.0 International License, which permits use, sharing, adaptation, distribution and reproduction in any medium or format, as long as you give appropriate credit to the original author(s) and the source, provide a link to the Creative Commons licence, and indicate if changes were made. The images or other third party material in this article are included in the article's Creative Commons licence, unless indicated otherwise in a credit line to the material. If material is not included in the article's Creative Commons licence and your intended use is not permitted by statutory regulation or exceeds the permitted use, you will need to obtain permission directly from the copyright holder. To view a copy of this licence, visit http://creativecommons.org/licenses/by/4.0/.

\section{References}

1. Ramdoo I. Unpacking local content requirements in the extractive sector: what implications for the global trade and investment framework. Geneva: International Centre for Trade and Sustainable Development; 2015.

2. Ovadia JS. Local content policies and petro-development in Sub-Saharan africa: a comparative analysis. Resour Policy. 2016;49:20-30.

3. Ngoasong MZ. How international oil and gas companies respond to local content policies in petroleum-producing developing countries. A narrative enquiry. Energy Policy. 2014;73:471-9.

4. Tordo S, Tracy BS, Arfaa N. National oil companies and value creation. World Bank. Working Paper No. 218. 2011.

5. Acheampong T, Ashong M, Svanikier VC. An assessment of local-content policies in oil and gas producing countries. J World Energy Law Bus. 2016;9:282-302.

6. UNEP Finance Initiative. Principles for Responsible Banking. Guidance Document: Reporting on the Principles for Responsible Banking. 2020. http://PRB-Guidance-Document-Final-19092019.pdf. (unepfi.org). Accessed 01 Mar 2021.

7. Obeng-Odoom F. Global political economy and frontier economies in Africa: implications from the oil and gas industry in Ghana. Energy Res Soc Sci. 2015;10:41-56.

8. Pegram J, Falcone G, Kolios A. Job role localisation in the oil and gas industry: a case study of Ghana. Extr Industr Soc. 2019;7:1-9.

9. Kazzazi A, Nouri B. A conceptual model for local content development in petroleum industry. Manage Sci Lett. 2012;2:2165-74.

10. Zaato JJ, Ohemeng FLK. Breaking the path in national development? The politics of public-private partnership in Ghana. J Strateg Contract Negot. 2017;2(4):326-46. https://doi.org/10.1177/2055563617710620.

11. Oppong N. Ghana's Public Interest and Accountability Committee: an elusive guest for 'home-grown' transformation in the oil industry. J Energy Nat Resour Law. 2016;34(3):313-36. https://doi.org/10.1080/02646811.2016.1179464.

12. Creswell JW, Plano Clark VL. Designing and conducting mixed methods research. Thousand Oaks: SAGE; 2018.

13. Ayanoore I. The politics of local content implementation in Ghana's oil and gas sector. Extr Industr Soc. 2020;7:283-91.

14. Owusu G, Bloch R. Linkages in Ghana's Gold Mining industry: challenging the enclave thesis. Resour Policy. 2012;37:434-42.

15. Panford K. Africa's natural resources and underdevelopment. how Ghana's petroleum can create sustainable economic prosperity. Palgrave Macmillan; 2017.

16. Overa R. Local navigations in a global industry: the gendered nature of entrepreneurship in Ghana's oil and gas service sector. J Dev Stud. 2017;53(3):361-74. https://doi.org/10.1080/00220388.2016.1184250.

17. Ablo AD. Scale, local content and the challenges of Ghanaians employment in the oil and gas industry. Geoforum. 2018;96:181-9.

18. Ablo AD. Local content and participation in Ghana's oil and gas industry: can enterprise development make a difference? Extr Industr Soc. 2015;2:320-7.

19. Ablo AD. Enterprise development? Local content, corporate social responsibility and disjunctive linkages in Ghana's oil and gas industry. Extr Industr Soc. 2019. https://doi.org/10.1016/j.exis.2019.09.003.

20. Heum P, Kasande R, Ekern OF, Nyombi A. Policy and regulatory framework to enhance local content. Yardsticks and best practices. In: Working paper. Presented at the 5th conference and exhibition on the petroleum potential and investment opportunities in East Africa. Thursday 3 February, 2011. Kampala Uganda.

21. Polkinghorne DE. Narrative configuration in qualitative analysis. In: Hatch JA, Wisniewski R, editors. Life history and narrative. London: The Falmer Press; 2001. p. 5-23.

22. Tanya VM, Hugh PM, Jennifer RPB. Exploring caring using narrative methodology: an analysis of the approach. J Adv Nurs. 2001;33(3):350-6.

23. Zaato JJ. Governance of state-owned enterprises and governance. In: Farazmand A, editor. Global encyclopaedia of public administration, public policy, and governance. Cham: Springer; 2017. https://doi.org/10.1007/978-3-319-31816-5_3237-1.

24. Singleton R, Straits B. Approaches to social research. 5th ed. Oxford: Oxford University Press; 2010.

25. Africa Centre for Energy Policy. Boosting indigenous Ghanaian companies participation in technical areas of Ghana's upstream oil and gas industry: a lesson study. ACEP. August. 2019.

26. Bowen GA. Document analysis as a qualitative research method. Qual Res J. 2009;9(2):27-40. https://doi.org/10.3316/QRJ0902027.

27. Hsieh HF, Shannon SE. Three approaches to qualitative content analysis. Qual Health Res. 2005;15(9):1277-88. 
28. Leite SP, Pellechio A, Zanforlin L, Begashaw G, Fabrizio S, Harnack, J. Ghana: economic development in a democratic environment. International Monetary Fund. Ghana: economic development in a democratic environment-IMF Occasional Paper No. 199. 2000. Accessed 03 Mar 2021.

29. Ministry of Finance. The budget statement and economic policy. 2020 financial year. Consolidating the gains for growth, jobs and prosperity for all. Ghana: economic development in a democratic environment-IMF Occasional Paper No. 199. 2020. Accessed 03 Mar 2021.

30. KPMG. Doing business in Ghana. 2020. https://assets.kpmg/content/dam/kpmg/gh/pdf/gh-Doing-Business-in-Ghana-2020.pdf. Accessed 19 sept 2020.

31. Natural Resources Governance Institute (NRGI). Ghana's oil and gas sector is best-governed in Sub-Saharan Africa, but challenges remain. 2017. https://resourcegovernance.org/news/ghana-oil-and-gas-sector-best-governed-sub-saharan-africa-challenges-remain. Accessed 19 Sept 2020.

32. Ghana National Petroleum Corporation. About us-overview. 2016. http://www.gnpcghana.com/overview.html. Accessed 19 Sept 2020.

33. Petroleum Commission. Petroleum Commission Ghana. About us. 2020. https://www.petrocom.gov.gh/organizational-brief/. Accessed 19 Sept 2020.

34. Natural Resources Governance Institute (NRGI). Reforming oil companies: nine recommendations. 2014. https://resourcegovernance. org/analysis-tools/publications/reforming-national-oil-companies-nine-recommendations. Accessed 19 Sept 2020.

35. Gyeyir DM. The Ghana stabilization fund: relevance and impact so far. Energy Policy. 2019;135:110989.

36. Adam A. Fronting in oil industry now a criminal offence. Graphics Online. 2018. https://www.graphic.com.gh/business/business-news/ fronting-in-oil-industry-now-a-criminal-offence-amin-adam.html. Accessed 20 Sept 2020.

37. McKinsey Global Institute. Reverse the curse: maximizing the potential of resource-driven economics. Chicago: McKinsey and Company; 2013.

38. International Energy Agency. World Energy Investment 2018. 2018. https://webstore.iea.org/download/summary/1242?fileName=Engli sh-WEI-2018-ES.pdf. Accessed 07 Oct 2019.

39. Ghana National Gas Company. Operations. 2020. https://www.ghanagas.com.gh/operations. Accessed 04 Nov 2020.

40. Ministry of Energy. Medium term expenditure framework (MTEF) for 2017-2019. 2017. https://www.mofep.gov.gh/sites/default/files/ pbb-estimates/2017/2017-PBB-MoEn.pdf. Accessed 19 Sept 2020.

Publisher's Note Springer Nature remains neutral with regard to jurisdictional claims in published maps and institutional affiliations. 